Journal of Humanities, Social and Management Sciences (JHSMS)

eISSN: 2788-4791 (online)

https://doi.org/10.47264/idea.jhsms/2.2.2

Vol. 2, No. 2 (July-December 2021), 13-25

https://ideapublishers.org/index.php/jhsms

Research Article

\title{
Kashmir dispute: Emerging complexities after abrogation of Article 370
}

\author{
Rizwan Ali*1 ${ }^{\text {Usman Mustafa }}{ }^{2}$
}

1. Department of Peace and Conflict Studies, National University of Science and Technology (NUST), Islamabad, Pakistan.

2. Pakistan Institute of Development Economics (PIDE), Islamabad, Pakistan.

*Corresponding Author Email: rashinwari@gmail.com

\begin{abstract}
Kashmir dispute is one of the contentious issues between India and Pakistan since their inception as independent states in 1947. This paper addresses this dispute that how it has been a primary cause of contention between India and Pakistan. How is it a huge humanitarian crises in the South Asia and ultimately the cause of a bulk of defence expenditures by India and Pakistan. Nonetheless, both the countries realize that the problem of Kashmir can and should be resolved through peaceful negotiations to reach a non-military solution. Both the states continue giving it a central importance in their internal and external policies. This resultant peaceful cooperation between the two nuclear powers is a central part of complex interdependence theory, which is used in this paper for analysing the issue. Thus, the paper investigates the Kashmir conflict and the cooperation between India and Pakistan to seek a peaceful resolution. The paper qualitatively assesses the situation emerged in the Kashmir after the abolishment of Article 370, for which some key people are interviewed. The findings show that the unilateral abrogation of the article 370 by the Modi government that changed the status of Kashmir further intensified the conflict and undermined the peaceful efforts made so far.
\end{abstract}

Keywords: India Pakistan relations, Article 370, UN resolutions, Kashmir dispute, insurgency in Kashmir, complex interdependence, Indo-Pak cooperation.

How to Cite:

Ali, R., \& Mustafa, U. (2021). The Kashmir dispute: Emerging complexities after abrogation of Article 370. Journal of Humanities, Social and Management Sciences (JHSMS), 2(2), 13-25. https://doi.org/10.47264/idea.jhsms/2.2.2

\section{Publisher's Note:}

IDEA PUBLISHERS (IDEA Journals Group) stands neutral with regard to the jurisdictional claims in the published maps and the institutional affiliations.

\section{Copyright:}

(C) 2021 The Author(s), published by IDEA PUBLISHERS (IDEA Journals Group).

This is an Open Access article published under the Creative Commons Attribution-NonCommercial 4.0 International License (http://creativecommons.org/licenses/by-nc/4.0/) 


\section{Introduction}

India and Pakistan are the two nations in the subcontinent whose interplay primarily determines the peace and stability in the whole region. They both do not enjoy good neighborly relations. The primary cause of conflict is over the Kashmir region. This issue has kept India and Pakistan violently engaged for over 70 years including four wars they fought (BBC, 2019a). These military adventurisms cost India and Pakistan billions of rupees and thousands of people dead. Initiatives and Group (2004) in its report "The cost of conflict between India and Pakistan", stated that apart from economic and financial cost, more than 20,000 soldiers and civilians died on both sides in the last four major wars. Even though, after paying this high cost and numerous attempts to decide their fate even at a diplomatic table, the Kashmir dispute remains unresolved (Kasuri, 2015).

There are many phases of the conflict in the disputed area of Kashmir (Figure 1). The phase started in 1988 onward had serious implications not only for Kashmir, but for India and Pakistan also. The political turmoil started by the Indian political parties were later exacerbated by the support of Pakistan to Kashmiri militants. Over 40,000 people died in this conflict since 1988 (South Asia Portal, 2021). Kashmir had a special status under the Article 370 of the Indian constitution. Unter this article, Kashmir had a semi-autonumous status (BBC, 2019b). In 2019, the article has been abrogated by the ruling BJP government which led to a mass human rights violations. This consititutional ammedment was not expected by anyone.

\section{Literature review}

The history of accession of Kashmir, and the violation of the UN security council resolutions by India and Pakistan had been debated by scholars in different ways. The available literature also missing the point if there are any links between the problem of Kashmir and its dependence on the normalization of Pakistan and India relations. To find the answer to these questions, the researcher recorded views of key people from India, Pakistan, the US and the Kashmiri leaders and activists. Most of the scholars are trying to address questions circling around the Kashmir issue. Alam et al. (2016, p. 13) made an endeavor regarding Kashmir and concluded that, by using lenses of realism, both India and Pakistan have no genuine intentions to resolve the issue, and that they are instead pursuing their national interests.

India would never try to let the Kashmir valley slip from its hands for everal reasons: it acts as a geographical barrier from Pakistan and China, thus granting Kashmir an independence would likely open conflicts at their homefront; and the valley is a host to natural resources, and these resources play a prominent role in the Indian economy. For Pakistan, the same valley possesses natural resources, including rivers, which irrigates southern Pakistan provinces of Punjab and Sindh (p. 18). Similarly, Sharma (2016, p. 280) reiterated that Northern areas of Pakistan, Jammu and Kashmir and Gilgit Baltistan, possess geostrategic and economic importance for India. Beyond this region are the Central Asian Republics (CARs) which can be a great market for Indian goods.

Adnan and Fatima (2016, p. 291) argued, regarding the Kashmir problem, that Pakistan is not willing to compromise on Kashmir with India because of its location at a critical geostrategic location. Pakistan is facing hegemonic threats from India and that any deal on Kashmir can be considered a strategic loss. Fair (2005, p. 1), in her United States Institute of Peace (USIP) 
report, India and Pakistan Engagement; Prospects for Breakthrough or Breakdown?, affirmed that India was in negotiation with the Kashmiri groups, and that negotiation was not possible due to Pakistan's alleged intervention of supporting Kashmiri separitists, and India wanted to resolve the longstanding issue which was necessary to achieve the ultimate goal that would help develop India into a global economic power. However, Fair showed lenses of pessimism regarding this peace deal and argued that it is highly likely for a breakdown and less likely for the breakthrough in a roadmap toward peace. It seems right that since this 2005 report, no comprehensive Kashmir agreement was reached (p. 2).

Some literature highlighted the cross-border ethnic identities as a new dimension of the Kashmir conflict. Dash and McCleery (2014, p. 33) argued about sub-nationalism and micronationalism under which Indian Muslims have deep cultural and religious affiliation and emotional attachments with Pakistani Muslims. The possible spillover of militants and millitary support from Pakistan has further aggravated the separatist movements in Indian-held Kashmir. India implemented inhumane laws to curb militancy in a brutal way which resulted into the rise of nonviolent political movements in the Indian-held Kashmir. This uprising in Kashmir made India accuse Pakistan of the restlessness and anarchy in the region. Pakistan reciprocally accused India of meddling in its Sindh and Baluchistan provinces (Haider, 2009). Such ethnopolitical issues further accentuated the already deteriorating atmosphere between India and Pakistan.

\section{Methodology}

The researcher interviewed a total of 15 key people from Pakistan, India, US, and the Kashmir. Some were interviewed before the abrogation of Article 370, and some were after. Views of some of them are included in this paper. Their views are analyzed along with secondary sources. The people interviewed were from different professions of life including social activists, politicians, academicians from universities and thank tanks, and natives of Kashmir.

\section{Kashmir and the complex interdependence theory}

The theoretical framework of complex interdependence presented by (Keohane \& Nye Jr, 1973) has been used in this research paper. It has three basic assumptions which define this research. The first assumption talks about using multiple channels among countries who are in interactions with each other. The second assumption discusses the absence of hierarchy among countries while resolving military and non-military disputes. The third assumption is very important especially for countries who are contiguous to each other and are at war most of the time. The third assumption of the Complex Interdependence theory define the using the military force is not always the primary choice in resolving political issues among nations.

The third assumption has been followed that define and frame Kashmir problems between Pakistan and India and how, if the issue can be resolved through non-military means, can boost up the development of the overall region of South Asia. For this purpose, it deemed important to discuss in details Kashmir as a main bone of contention between India and Pakistan. Under these circumstances of peaceful resolution, the marginal safety has been widened between Pakistan and India because the cost of going to war is increasing with the passage of time with no observable, and tangible benefits. This is also the reason both the countries, for a longer time, have been trying to involve some other major powers for the resolution. Both countries 
have recognized the fact that going to war over the issue of Kashmir is not going to solve this problem but rather it will exacerbate their security and economic situations. They also know that it can further aggravate the prevailing poverty in their countries.

There are cases of other industrialized countries who fought wars with their archenemies centuries ago and they are now considering mutual cooperation. France has stopped the policy of tous azimuths (defense in all direction) initiated by president De Gualle. Similarly, Canada in the past, considered going to war with the United States but now they both are doing multidimensional trade with each other. Same was the case with Germany and Britain and they no longer are a threat to each other. All these countries lived under the fear of war but now the use of force is no more a primary instrument of their foreign policies.

\section{History of insurgency in Kashmir}

From 1947 until the late 1980s, there was relative peace in the Jammu and Kashmir region under the control of India. A severe wave of the insurgency started in 1987 which is still present in the valley and caused deaths to thousands of people, including Kashmiri civilians, insurgents, and Indian military troops (Farooq, 2019), in Figure 1 also.

Figure 1: Fatalities in Violence in Jammu and Kashmir (J\&K): 1988 - 2019

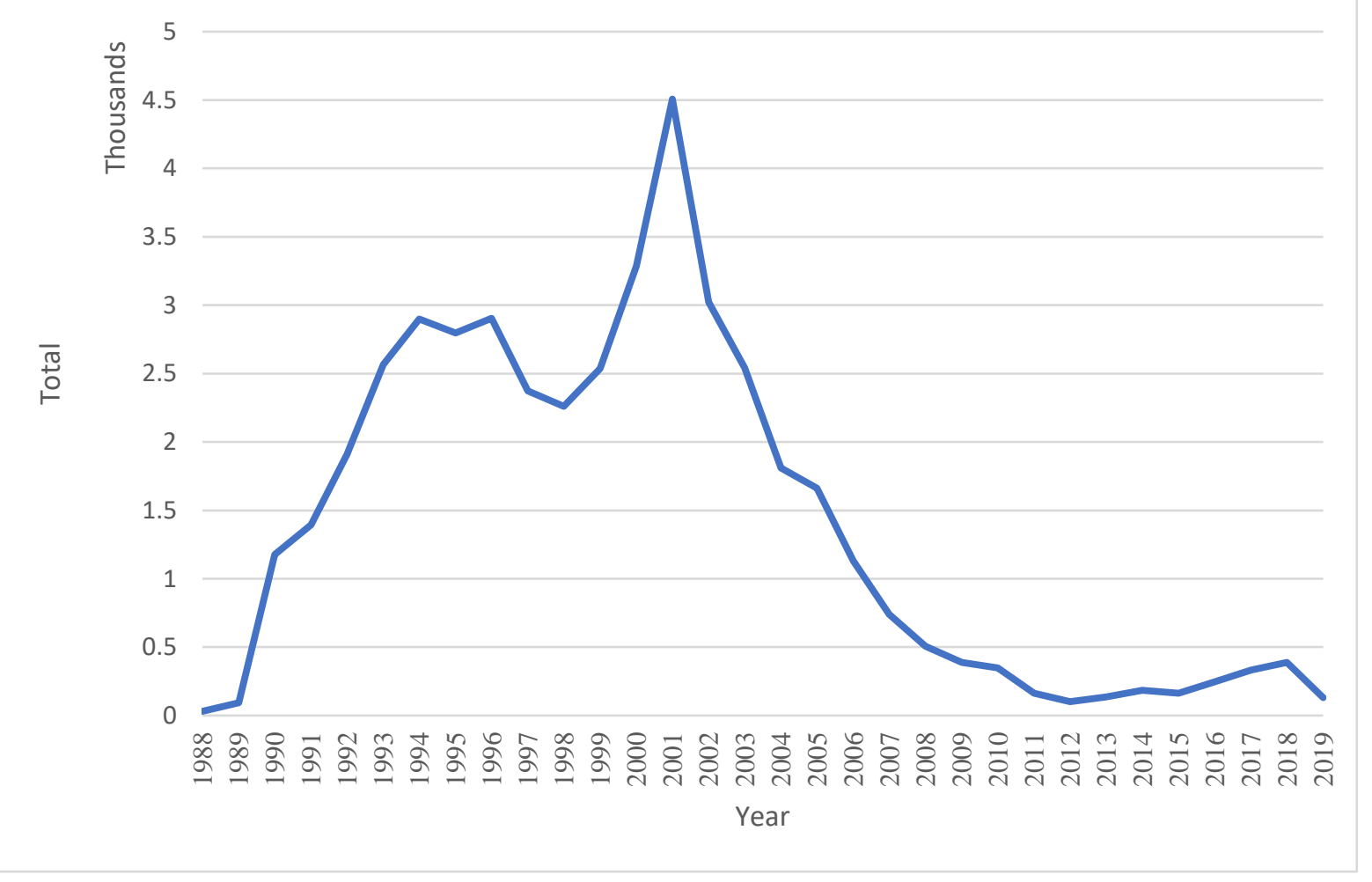

Source: Union Ministry of Home Affairs, India (UMHA). Data till March 31, 2019

The Kashmir insurgency can be divided into two distinct phases. The first phase, from 19871989 is called the build-up to insurgency. The second phase, 1989 to the present, is called actual scale insurgency. The next phase is in progress, internationalization of the Kashmir conflict, which moved from Indian Kashmiri-Muslim vs Indian forces escalation to the direct conflict between India and Pakistan (Malik \& Wirsing, 2002). 
The buildup of the insurgency started somewhere in 1989. But there are reports of two major events in 1960s which were significant in nature and attracted the attention of the international community. There were two groups which had been involved in the decades of 1960s and 1970s in sabotage activities in Kashmir: al-Fatah and the Jammu and Kashmir Liberation Front (JKLF). Both groups carried out small scale assaults on police authorities and were involved in other sabotage activities. In early 1971, the third group, Kashmir Liberation Front (KLF) hijacked an Indian airline. This was the first high magnitude act of militancy carried out by militants of Jammu and Kashmir since 1947. Similarly, in February 1984, an Indian diplomat named Ravindra Matre was kidnapped in England by the Kashmir Liberation Army (KLA), a group thought to be closely linked with JKLF. They asked for Matre to be exchanged for the JKLF leader, Maqbool Butt, who was in Indian prison and sentenced to death for killing an Indian judge. They also demanded 1 million British pounds in ransom. During this negotiation process, the Indian diplomat was killed, and the Indian court carried out the execution order of Maqbool Butt.

These events coupled with prevailing political instability further escalated the insurgency in the valley in the latter 1980s. After the death of Sheikh Abdullah, a key figure in the accession of the Jammu and Kashmir with India, his son Farooq Abdullah came to the surface as a political figure in the valley. In 1987's election, both Abdullah and Rajiv Gandhi made alliance and rigged elections in which Abdullah was elected. This led to insurgency by those who lost the contest in the election. According to many reports, Pakistan provided training, recruits, arms, and logistic support to these groups (Jamal, 2009). About the 1987's election and how it led to insurgency, according to Fai, N. (personal communication, October 28, 2020), an exiled activist, mentioned:

In 1989, the youth of Kashmiri initiated the armed struggle...The symbol of that armed struggle, his name is Syed Salahuddin, his real name is Muhammad Yousuf Shah. He was contesting the election for the local assembly from Indera codal constituency, and the ruling party candidate from Sheikh Abdullah party was Ghulam Muhioddin Shah. Muhammad Yousuf Shah was contesting from the platform of MUF (Muslim United Front). And Muhammad Yasin Malik was an election agent. So, election took place, Salahuddin was winning by 14,000 votes. The counting was still going on, but there are only few votes left. So, they say okay, let us go to the mosque pray shukr, and thank God Almighty and when we had to make the Salat anyway. Then they came out and they made the Salat, now they are celebrating. So, there was a young boy. And he knew Sallahuddin, he said Shah Sab! why are you so happy? He said, because we won the election. That time there was no TV but he was listening to All India Radio, that young boy said, what I just listened All India Radio said that you are losing by 14,000 words. And he was arrested from that place from the mosque and put in the jail, not alone but all the candidates of MUF, except Syed Ali Gillani. By the way, Syed Ali Gilani won. Because they did not do the ragging there, and they could not do that much rigging from Gilani sab constituency. So, he was not alone there, there were five candidates who are declared successful, but they could have formed the government. That was in 1987.

You see what I'm saying? It is the Kashmiri youth, they said "we tried to go through the democratic process. And we were winning, and they said no, you are losing". I K Gujral, he was the prime minister, and he said here in Chicago. He said here in Chicago. "The one of the reasons of uprising in Kashmir was the rigging of elections in Kashmir". So, they took the arms. By the way, according to the UN charter, "if you are occupied, you can have the armed 
struggle. But it has to be only for the military purposes, you cannot use it against the civilians". But that was then. When in 2008, the youth of Kashmir came to Gilani sahib, Gilani sab did not go to them, they came to Muhammad Yasin Malik, they came to Umar Farooq, they brought them out of their houses, youth was in 10s of thousands in number. They told them, "You lead us, but we have to have this peaceful moment". So, from 2008, they really changed the nature of Kashmir freedom moment into a peaceful moment, that Veer Samvi I told you Hindustan Times, Swami Ayyar I told you Hindustan Times, the reason they wrote those articles because they know the people of Kashmir, they are initiating the peaceful movement. If there was a gun, it would have been very difficult for them to see what they said. You see what I'm saying? It would have been very difficult for Chandam Bharam to say, "if you want Kashmir to love India, let us have a referendum".

So yes, still there are some guns, but you know that is that reaction to the atrocities. And I haven't listened to the governor of Kashmir, more than a dozen times. They have said that we crushed the militancy in Kashmir, there are 200 left, there are 300 left, there are 400 left. They never said there is 1000 there, and you tell me Rizwan, if you are really crushing the militancy and you are saying there are 300 left, what is 900,000 Indian Army doing there? So, what it is not that militancy which matters in Kashmir, it is the peaceful nature of the people of Kashmir. I'm not saying $300 \ldots$ the governor of Kashmir saying, "we crushed, we finished the militancy, there are only a few hundred left". So, if you have to really crush the few hundreds, don't have 900,000 . So, he is coming to a question that the strength of the Kashmir struggle is the reason the United Nations High Commission on Human Rights, not because I send them reports. They have their own reports. They know, yes in fact there are people in Kashmir, maybe 100 or 200 or 300 they have the gun. But millions of Kashmiris, they want peaceful resolution. They know that. Otherwise, why should they speak for the people of Kashmir. See this 47-page report which you are going to get from the Google. See document the nature of atrocities, not only that atrocities, the nature of atrocities, no doubt they have also mentioned there are some militants they are doing this, they are doing that. But as of today, how many militants are there? Burhan Vani? you have a heard Burhan Vani?

JKLF carried out mass-level militant activities in 1989, in which more than 100 Indian officials were killed. It almost paralyzed the intelligence operations and government administration in the Indian-held Kashmir. The daughter of Mufti Mohammed Sayeed - then home minister of India-was kidnapped and was released after the Indian government releasing four terrorists by the demand of JKLF. Farooq Abdullah resigned in response to Jagmohan Malhotra as governor of the Jammu and Kashmir which led to the political upheaval in the state. The state went under governor's rule under the Article 92 of the state constitution. The JKLF leadership had initiated protests in the valley, triggering the Indian government to call paramilitary units which were previously involved in fighting the Maoist insurgency in the north and northeastern states of the Indian union territory. The geographic terrain in the Jammu and Kashmir and mode of fighting was different for these forces and it caused more than 50 casualties in the Gawkadal massacre (Ehsan, 2005). The Indian government turned more violent against these militants and implemented the Armed Forces Special Power Act (AFSPA) in September 1990 in which forces were granted special power to kill and arrest to maintain public order. It had deep impacts on the public as these forces were free to kill prominent political figures (Human Rights Watch,2008). With the passage of time, there was increase of the militant groups getting involved in the insurgency alongside JKLF. They included People's League, Hizb-i-Islamia, Allah Tigers, Hizbul Mujahadeen, Harkat ul Ansar, Al-Faran, Lashkar-E-Taiba, Jaish-e- 
Mohammed, and few other small groups. The main JKLF was operating under Ashfaq Majid Wani, and accompanied by Hamid Sheikh, Yasin Bhat, and Irfan Ahmad, and, Javed Mir (Sumantra, 2003, p. 146).

In 1989, militancy had been reshaped and Islamized by the above-mentioned militant groups in the valley of Jammu and Kashmir. In this process, the political setup in Kashmiri culture had been Islamized for the purpose to prepare for the merger of Kashmir with Pakistan. Many militant groups asserted that their struggle would continue until the establishment of an Islamic caliphate in Kashmir. As a part of this process, mass-level religious persecution of nonMuslims including majority Hindus occurred which forced the Hindus to migrate from the Jammu and Kashmir and settle elsewhere in India. Similarly, wine shops, cinema houses, bars, beauty parlors, were banned by these groups. Not only these militants but the Kashmiri politicians, including Abdullah and his government, pursued Islamization policies during 1980s. Notably, his government changed the names of 2,500 villages to Islamic names (Bakaya \& Bhatti, 2005).

\section{Musharraf formula on Kashmir Resolution}

Kashmir has always been a cause of India-Pakistan conflicts and resulting peace negotiations. The dialogues between India and Pakistan starting in the 1990s were called the Composite Dialogues and were centered on issues of regional stability in both countries. After 2004, the scope of these dialogues had been extended to include Kashmir too, and called it the Comprehensive Dialogues (IPRI, 2015). For the first time in seven decades, both India and Pakistan reached towards Kashmir resolution at the Agra Summit when Pervez Musharraf, then-president of Pakistan, presented his popular Four-Point-Formula for the Kashmir resolution. According to Khurshid Mahmood Kasuri (Kasuri, 2015) in Neither a Hawk nor a Dove, the solution of Kashmir was in the grasps of both governments, but it slipped away. Musharraf's four points were: 1) phased withdrawal of troops; 2) no change of borders of Kashmir and the people will move freely across the border; 3) both the regions will be under one governance which will be ruled by the Kashmiris themselves, and 4) joint supervision mechanism under the auspices of India-Pakistan in Kashmir. Leaders of India and Pakistan both were in favor of autonomy to the Kashmiri people. The third point was also in accordance with the Indian Constitution of autonomy under the Article 370.

\section{Politics and other drivers of conflicts in Kashmir}

There are three main drivers of the Kashmir conflict: secular nationalism by India; the Kashmiriyat - by the Kashmiri nationalists; and religious nationalism by Pakistan. In this vicious triangle, each side is blaming the other of being the primary driver of conflict. Pakistan came into being on the notion of the Two Nations Theory (TNT) which was based on the pretext that Hindus and Muslims are two different nations living in India, and so as Kashmiri Muslims. Based on the theory, Pakistan was striving to include the state of Kashmir into its territory as India did with the Hindu majority states elsewhere in the Indian subcontinent. Pakistan faced difficulties when this decision of Muslim states joining Pakistan was neither accepted by the Maharaja nor by Muslim leaders of the Kashmir's National Conference party. Leaders of the Muslim Conference, notably Sheikh Abdullah (father of Farooq Abdullah), was fighting the Maharaja during the same time. Sheikh Abdullah, in his statement to the Security Council in 1948, mentioned, 
"I and my organization never believed in the formula that Muslims and Hindu form separate nations. We did not believe in the Two-Nation Theory, not in the communalism or communalism itself. We believed that religion had no place in politics” (UN Security Council, 1948).

In 1947, a total of 65 million Muslims from Pakistan and Bangladesh separated from India, leaving behind 35 million Muslims in India. On the other hand, Muslims in Kashmir alone were only 4 million. In these circumstances, pushing hard for Kashmir and supporting Kashmiri separatists to detach themselves from India were endangering the status and lives of millions of Muslims in India. Indian Muslims were deeply affected by Pakistan's motives. Pakistan's desire for separate homelands for Muslims in Kashmir and elsewhere in India put a question mark on the Theory itself and the demise of this theory was further confirmed after the separation of Bangladesh from Pakistan. In these circumstances, the question raised whether there needs to be further division in India for the Muslims, with Kashmir being the third nation? Muslim leaders in India anticipated these implications of Pakistan's actions in Kashmir. Over two dozen notable Indian Muslims submitted a memorandum to the United Nations (Varshney, 1991) in 1951 saying:

Pakistan has made our position weaker by dividing out Hindus from western Pakistan in utter disregard of the consequences of such a policy to us and our welfare... Such a policy must inevitably, as the past has already shown, result in uprooting of Muslims in this country... It is a strange commentary on political beliefs that the Muslims of Pakistan who would like the Muslims of Kashmir to join them, invaded the state in October 1947... In its often proclaimed anxiety to rescue the three million Muslims from what it describes as the tyranny of a handful of Hindus in the Jammu and Kashmir state, Pakistan evidently is prepared to sacrifice the interests of 40 million Muslims in India, a strange exhibition of concerns for the welfare of fellow Muslims. Our misguided brothers in Pakistan do not realize that if Muslims in Pakistan can wage war against Hindus in Kashmir why should not Hindus, sooner or later, retaliate against Muslims in India?... Does Pakistan seriously think that it could give us any help if such an emergency arouses? It is incapable of providing room and livelihood to the 40 million Muslims of India should they migrate to Pakistan. Yet, its policy in action...may well produce that result (Varshney, 1991).

Millions of Muslims who migrated to Pakistan from India during partition faced identity problems in Pakistan which also put a question mark on what could have been the status of Kashmiri Muslims if they could become a part of Pakistan. For a long time, Muslims who migrated from India into Pakistan were struggling and were known by the title of Muhajirrefugee. They were struggling for decades to have their identity. They have their own political party Muttahida Qaumi Movement or MQM, representing people who migrated from India. They are mostly located in the southern commercial hub city of Karachi, Pakistan.

Kashmir was a test case for the secular nationalists, especially the Indian National Congress. The Congress was promoting the idea of nationalism which was not based on communal or religious ideology. On the other hand, the Hindu nationalists were promoting the idea of religious nationalism and were in ideological clash with the secular nationalists over the status of Indian Muslims. If Kashmir became part of Pakistan, it would have bolstered the theory of 
Hindu nationalists. Hindu nationalists always claimed that Muslims are not loyal to India and that Muslims did not recognize the fact India is primarily a Hindu civilization. They tried to hijack the mandate and subdue this ideology of Congress, but they were not successful.

It was a challenge for Nehru to use Kashmir as a determinant of his secular ideology and of the secular mandate of the Congress party which was a representative of the Indians against the British Empire. He wanted Kashmir to stay in India so that the Hindu nationalist ideology stays in the corner. He argued that Kashmir must stay in India:

We have always regarded the Kashmir problem as symbolic for us, as it has far reaching consequences in India. Kashmir as symbolic as it illustrates that we are a secular state... Kashmir has consequences both in India and Pakistan because if we disposed of Kashmir on the basis of the Two Nation Theory, obviously millions of people in India and millions in East Pakistan will be powerfully affected. Many of the wounds that had healed might open out again (Govt of India, 1953).

He was right about the wounds as he recently saw the disaster of partition in which more than a half million people were killed and over 15 million crossed borders at either side. Killings and migration of this magnitude were the largest of the 20th century (Encyclopedia Britanica, 2016). The challenge of the Congress party, in tackling the Hindu nationalist movement and never lose Indian nationalist ideas, became much more complicated in the1960s when Hindu nationalists started movements in Kashmir. It continued for almost two decades and resulted in Muslims separatist movements in Kashmir in the 1980s which were followed by the unending bloodshed, the killing of more than 40,000 people (Figure 2). After the partition, Nehru tried to stop the chances of this menace of bloodshed. After the 1990s, there was a rise of hatred and killings by the Hindu nationalist parties against Muslims, particularly in the state of Jammu and Kashmir. This Hindu nationalist's violence had multidimensional impacts by endangering the secular Indian nationalists' ideology while bolstering Kashmiri nationalists which thus gained sympathies from Pakistan. If somehow Kashmir would have became a part of Pakistan under these circumstances, the primary beneficiaries would have been the hardcore Hindu nationalists in India.

\section{Special status under Article 370 in the constitution of India}

Article 370 of the Indian Constitution provides a special status to Jammu and Kashmir region which is under the control of India (BBC, 2019b). There were speculations in India, Pakistan, and Kashmir around scrapping Article 370 and 35-A-Article that grants special privileges for the people of the Valley of Kashmir. But, in August 2019, the Indian government announced revocation of article 370, merging Kashmir into the Indian union territory. Article 370 was a bridge that kept semi-autonomous Kashmir connected with India for nearly 70 years, which is now a part of the Indian union territory.

The Article 370 defined the Indian government's sphere of influence in some key matters in Kashmir including defense, foreign affairs, and communication of the state, while the state had the complete autonomy to have its own constitution, separate flag, and autonomy to make legislations and laws related to its residents. The state also had the authority to define ownership laws and stop outsider Indians from making land purchases in the Valley. This 
article had many dimensions, one of which was to keep the Kashmir the only Muslim majority state - with $68.3 \%$ of the state population - in India (India, 2011). With the revocation of this article, the population landscape will drastically change in the coming years. According to Fai (personal communication, October 28, 2020), there are 0.9 million Indian forces, and 1.7 million labors who are living in Kashmir for over a decade, can now get the domicile in Kashmir, according to the new rules, and it can drastically change the population equation.

The current BJP government of Nahrendra Modi came into power with the promise that it will bring massive changes related to Kashmir and Muslims in the country. BJP is the Hindu nationalist party which had been striving for strict measures against Muslims in India. According to BJP, scrapping Article 370 is important to integrate Kashmir and bring it on the same footing with the rest of India. With the change of its status, Kashmir will no longer have autonomous authority and it will have to abide by the Indian constitution, just like the rest of the states. The outsiders from rest of the Indian states can now be treated the same and move around Kashmir freely and can purchase lands there. The BJP ${ }^{1}$ government felt Article 370 was a hindrance to development. According to Indian interior minister Mr. Amit Shah:

I want to tell the people of Jammu and Kashmir what damage Article 370 and $35 \mathrm{~A}$ did to the state. It is because of these sections that democracy was never fully implemented, corruption increased in this state, that no development could take place (BBC, 2019c).

The state of Jammu and Kashmir had three geographical parts: Muslim-majority Kashmir, the Hindu-majority Jammu, and the Buddhist-majority Ladakh (Figure 2). According to the initial plans, the Indian government is dividing the area into two territories which will be federally administered. In one region, the Jammu and Kashmir area will be combined, and in other area will be the Ladakh. The revocation of Article 370 has given birth to unstoppable human rights violation by the Indian government. This question was asked by the researcher from the key people who were interviewed. On the implications and the human rights violations, according to Kashmiri activist, Annon ${ }^{2}$, G. (personal communication, December 12, 2020) mentioned:

There was no communication between people. And like all our autonomy was taken away from us, this was the only thing, these Article 370 and 37-A, these were two threads that we were hanging on to protect our land, to protect our indigeniousty, to protect basically ourselves. But after that was taken away from us, we became so vulnerable and ready to be eaten up.

Kashmiris on both sides across the border are not satisfied with India and Pakistan's approach to the treatment of the Kashmir problem. Another informant and a professor from Pakistancontrolled Kashmir, Qaesar, R. (personal communication, February 08, 2018), mentioned:

Being a Kashmiri, we want a solution to this issue. We want a peaceful solution to these issues, we want end to ridiculing from both the sides, ending AFSPA from the Indian side, killing and raping should be stopped. We are in favor of peace in the Valley. They both should stop making lives of the Kashmiris miserable. They are blackmailing each other, and Kashmiri people are crushing in the middle. They have excuses to one another. 
Similar views were expressed by exiled Kashmiri activist and politician, Fai, N, (personal communication, October 28, 2020). He was disappointed by the political steps taken by Prime Minister Imran Khan, to respond to India. He mentioned,

United Nations did not give them (India and Pakistan) the right to the Valley of Kashmir and the Gilgit Baltistan. Yet Imran Khan sab knows Gilgit Baltistan is not a part of Pakistan, if you are making it a part of Pakistan you are making a big mistake. Why? Because you are giving an excuse to India what you (they) did last year. God bless you; we (Pakistan and Kashmiri politicians) are doing the same thing. So United Nations gave the right to Gilgit Baltistan, Azad Kashmir, Jammu, Laddakh, Valley.

There is a narrative propagated by the ruling BJP government that Kashmiris should receive similar treatment with the Indians. Sharing her views, according to activist from India, Annon ${ }^{3}$, D. (personal communication, December 12, 2020),

This idea of equality, like, why not, why should they (Kashmiris) not get equal rights, why should they not get the same, and why should they get a special thing when we are supporting them when our armies are there, they (Indian army) are always helping them during floods and even during earthquake and they're always protecting them against the terrorists and all. So why is it that Kashmir is not still our part?

\section{Conclusion}

Kashmir is strategically, economically, and political important region in South Asia. It is a major source of tension between India and Pakistan. These tensions are ultimately giving birth to perpetual poverty in both the countries. Special measures like the Comprehensive Dialogue were initiated, and it need to be taken and made its periodic induction mandatory for both India and Pakistan. Some amendments should be made to these dialogues as political scenarios keep on changing - the recent amendments in Article 370 by the Indian government - and new problems will likely occur in the future. Key international players like the United Nations and the United States need to play an influential role to minimize the outbreak of another war, especially implementing the resolutions passed toward the issue of Kashmir. The United Nations should make sure their efforts and energy are not wasted and yield intended results.

The same major players need to involve India and Pakistan in healthy relations in fields of energy and trade cooperation with which they would divert their energy from wars to cooperation and peace. The United States needs to understand it is important for India and Pakistan to get involved with Iran for their energy demands through energy trade. After getting involved in the trade, it will be less likely for India and Pakistan to go to war with each other. Pakistan needs to understand the dangers of arming and supporting the insurgents in the Kashmir, as this process can incite India of reciprocating in Pakistan's Baluchistan province. 


\section{References}

Adnan, M., \& Fatima, B. (2016). Peace process with India: A challenge for Pakistan. South Asian Studies, 31(1), 291-303. http://journals.pu.edu.pk/journals/index.php/IJSAS/article/viewFile/3047/1258

Alam, M. S., Ali, G., M., \& Hasan, M. (2016). Kashmir conflict between India and Pakistan: A realist perspective. Journal of Asian and African Social Science and Humanities, 2(1), 13-23.

Farooq, A. (2019, August 4). Heightened security and anxiety in Kashmir amid fears of unrest. The Guardian. https://www.theguardian.com/world/2019/aug/04/heightenedsecurity-and-anxiety-in-kashmir-amid-fears-of-unrest

Bakaya, P., \& Bhatti, S. (2005). Kashmir conflict: A study of what led to the insurgency in Kashmir Valley and proposes future solutions. Swords and Ploughshares, 16, 1-4.

BBC. (2019a). Kashmir: Why India and Pakistan fight over it. $B B C$ News https://www.bbc.com/news/10537286

BBC. (2019b). Article 370: What happened with Kashmir and why it matters. BBC News. https://www.bbc.com/news/world-asia-india-49234708

BBC. (2019c, August 6, 2019). Article 370: What happened with Kashmir and why it matters. BBC News. https://www.bbc.com/news/world-asia-india-49234708

Dash, K. C., \& McCleery, R. K. (2014). The political economy of trade relations between IndiaPakistan. Journal of Economic \& Financial Studies, 2(02), 26-40. https://www.journalofeconomics.org/index.php/site/article/view/132

Ehsan, M. (2005, May 1, 2005). Kashmir's first blood. The Indian Express. https://indianexpress.com/article/news-archive/kashmirs-first-blood/

Encyclopedia Britanica,. (2016). Human Migration. In.

Fair, C. C. (2005). India and Pakistan engagement: Prospects for breakthrough or breakdown? (Vol. 129): United States Institute of Peace.

Govt of India. (1953). Jawaher Lal Nehru speeches, March 1953 to Augusut 1957. http://ignca.gov.in/Asi_data/59309.pdf

Govt. of India, (2011). India Census 2011. https://www.census2011.co.in/religion.php

Haider, Z. (2009, APRIL 22, 2009). Pakistan accuses India, Afghans, of Baluch meddling. Reuters. https://www.reuters.com/article/idINIndia-39181020090422

Human Rights Watch. (2008). Getting away with murder 50 years of the Armed Forces (Special Powers) Act [Press release]. https://www.hrw.org/legacy/backgrounder/2008/india0808/

Initiatives, I. C. F. P., \& Group, S. F. (2004). Cost of conflict between India and Pakistan: Strategic Foresight Group.

IPRI, (2015, September 15, 2015). Analysis of Pak-India composite dialogue. Islamabad Policy Research Institute. https://ipripak.org/analysis-of-pak-india-compositedialogue/

Jamal, A. (2009). Shadow war: The untold story of Jihad in Kashmir. Melville Publishing.

Kasuri, K. M. (2015). Neither a hawk nor a dove: An insider's account of Pakistan's foreign relations including details of the Kashmir framework. Oxford University.

Keohane, R. O., \& Nye Jr, J. S. (1973). Power and interdependence. Survival, 15(4), 158-165.

Malik, I., \& Wirsing, R. G. (2002). Kashmir: Ethnic conflict international dispute. Oxford University.

Sharma, V. (2016). Kashmir: Unresolved issue between India and Pakistan. Indian Journal of Applied Research, 6(2), 3. https://www.worldwidejournals.com/indian-journal-of- 
applied-research-(IJAR)/article/kashmir-unresolved-issue-between-india-andpakistan/ODUwNw==/?is $=1$

South Asia Portal. (2021). Archive Data - Jammu \& Kashmir. https://www.satp.org/datasheetterrorist-attack/reference-data/india-jammukashmir

Sumantra, B. (2003). Kashmir: Roots of conflict, paths to peace. Vistaar, New Delhi.

UN Security Council, (1948). Sheikh Abdullah Statement on Kashmir. United Nations (UN). https://www.satp.org/satporgtp/countries/india/states/jandk/documents/papers/excer pts_of_sheikh_abdullah\%27s_february_5_1948_speech.htm

Varshney, A. (1991). India, Pakistan, and Kashmir: Antinomies of Nationalism. Asian Survey, 31(11), 997-1019. https://doi.org/10.2307/2645304

\section{Notes:}

${ }^{1}$ Bharatiya Janata Party or BJP is the right-wing ruling party in India in office since 2014. It is deeply rooted into the Hindu nationalism. It is the world's largest political party in terms of membership.

${ }^{2}$ Informant preferred to stay anonymous.

${ }^{3}$ Informant preferred to stay anonymous. 